\title{
The Elasticity of Taxable Labour Income in the Netherlands*
}

\author{
Egbert L.W. Jongen ${ }^{\dagger} \quad$ Maaike Stoel ${ }^{\ddagger}$
}

July 2019

\begin{abstract}
We study the elasticity of taxable labour income in the Netherlands. We use a large and rich data set, including both financial and demographic variables, for the period 1999-2005. The 2001 tax reform generates large exogenous variation in marginal tax rates at different segments of the income distribution. For all workers, we find an elasticity of 0.10 in the short run, 1 year after the reform, rising to 0.24 in the medium to longer run, 5 years after the reform. Furthermore, we find that the elasticity is higher for higher incomes and for women. Also, we find that the elasticity of taxable labour income is higher than the elasticity of (contractual) annual hours worked.
\end{abstract}

JEL codes: H24, H31, J22

Keywords: Elasticity of taxable income, hours worked, Netherlands

*We are grateful to Maya Verhoeve and Floris Zoutman for their assistance in calculating the effective marginal tax rates. We have benefitted from comments and suggestions by the editor Marno Verbeek, two anonymous referees, Leon Bettendorf, Nicole Bosch, James Browne, Koen Caminada, Kees Goudswaard, Jonathan Goupille, Bas Jacobs, Henrik Kleven, Marike Knoef, Tuomas Kosonen, Arjan Lejour, Emmanuel Saez, Hakan Selin, Hendrik Vrijburg, Dinand Webbink, Floris Zoutman and seminar and congress participants at CPB Netherlands Bureau for Economic Policy Analysis, Leiden University, the Tinbergen Institute Rotterdam, the CPB Workshop Behavioural Responses to Taxation and Optimal Tax Policy 2013, IIPF 2013, EALE 2013, Journées LAGV 2015 and the ZEW Workshop on Behavioural Responses to Income Taxation 2015. Remaining errors are our own.

${ }^{\dagger}$ CPB Netherlands Bureau for Economic Policy Analysis, Leiden University and IZA. Corresponding author. CPB, Bezuidenhoutseweg 30, 2594 AV, The Hague, The Netherlands. Phone: +31-6-50746439. E-mail: e.l.w.jongen@cpb.nl.

${ }^{\ddagger}$ Ministry of Economic Affairs and Climate Policy. E-mail: m.stoel@minez.nl. 


\section{Introduction}

Following the seminal contributions by Feldstein (1995, 1999), the recent public finance literature has focused on the so-called elasticity of taxable income (ETI) to measure the behavioural responses to changes in taxation. The ETI is a more comprehensive measure of behavioural responses to changes in taxation than e.g. the labour supply elasticity because it captures the full range of tax base responses including effort, occupational choice, tax avoidance and tax evasion. The ETI may therefore provide a better measure for the efficiency costs of taxation, although there is an active debate on whether or not the ETI is a sufficient statistic to measure the deadweight loss from taxation (Chetty, 2009; Saez et al., 2012; Doerrenberg et al., 2017).

In this paper we estimate the ETI for the Netherlands. Specifically, we consider the responsiveness of taxable labour income of employees to changes in (effective) marginal tax rates. We use a rich data set, the Labour Market Panel of Statistics Netherlands (2009), that contains both taxable labour income data from the Tax Office and a large number of socioeconomic variables taken from the Labour Force Survey (education) and from the municipalities (ethnicity) that are typically absent from tax return data. Furthermore, for a subset of workers, the Labour Market Panel also contains data on contractual annual hours worked. For this groups we can also compare the ETI with the elasticity of (contractual) annual hours worked. The data set covers the period 1999-2005. The 2001 tax reform in the Netherlands generates large exogenous variation in marginal tax rates at different segments of the income distribution.

We estimate the ETI by running a regression of the change in log taxable labour income on the change in the log of the net-of-tax rate $(1$ minus the effective marginal tax rate) and a number of controls. ETI studies typically look at either the elasticity of broad income (before deductions) or the elasticity of taxable income (after deductions) as the dependent variable. Our outcome variable of taxable labour income is closer to the concept of broad income than to the concept of taxable income, taxable labour income is broad income minus work-related deductions but before personal deductions. ${ }^{1}$ The empirical literature on the ETI has identified a number

\footnotetext{
${ }^{1}$ The taxable labour income variable that we use is very close to the concept of adjusted gross income in the US.
} 
of concerns that we need to address. One concern is the endogeneity of the marginal tax rate. In a tax system with rising marginal tax rates, a higher income leads to a higher marginal tax rate when the individual moves to a higher tax bracket. This creates a relationship between the error term and the net-of-tax rate and therefore leads to biased estimates. Following Auten and Carroll (1999) we deal with this problem by using synthetic net-of-tax rates as an instrument for actual net-of-tax rates. Specifically, we project income forward using average income growth, and calculate synthetic marginal tax rates using this projected (exogenous) income.

Another concern is mean reversion in income growth. Individuals that experience a positive (negative) shock in income in one period are more likely to have lower (higher) subsequent income growth than individuals that do not have a positive (negative) shock to income. This leads to mean reversion in incomes. When the reform targets mostly low-income groups or high-income groups this may again lead to a bias in the estimates of the ETI, also when we use synthetic marginal tax rates. Again following Auten and Carroll (1999), we control for mean reversion by including log base-year income in the control variables.

A further concern are other exogenous group-specific changes in income. For example, skill-biased technological change or globalisation may cause the incomes of high-wage earners to rise faster than the incomes of low-wage earners. If the reform targets high-wage earners we run the risk of confounding the treatment effect of the change in tax rates with differential trends for different income groups. We argue that this is less of a concern in our case. First, we show that the income distribution was stable over the decade before the reform, similar to the case of Denmark studied in Kleven and Schultz (2014). Second, also similar to Kleven and Schultz (2014), we study a reform that led to significant changes in marginal tax rates for different groups of the income distribution, not just high-wage earners but also low- and middle-wage earners, and within some groups we have both positive and negative changes as well. Third, similar to Kleven and Schultz (2014), we have a data set that includes socioeconomic variables. This allows us to control for differential trends for individuals with different socioeconomic characteristics like the level of education and ethnicity. However, as a robustness check we also consider the solution to differential trends offered by Gruber and Saez (2002), they control for differential trends across the income distribution by including a spline in log base-year income in the set of controls. 
Our main findings are as follows. In our base specification we find an ETI of 0.24 for all workers. This ETI is robust to different ways of controlling for exogenous income growth, the income cutoff and the choice of base year. For workers with a high income ( $>50 \mathrm{~K}$ euro) the ETI is higher, though the exact value of their elasticity depends on the way we control for exogenous income growth. We also find that the ETI is higher for women than for men. Finally, we find that the ETI is higher than the elasticity of (contractual) annual hours worked.

We make three contributions to the literature. First, we present the first estimates for the ETI in the Netherlands using the Gruber and Saez (2002) methodology. ${ }^{2}$ Indeed, there is a large number of ETI studies for Anglo-Saxon countries (e.g. Feldstein, 1995; Auten and Carroll, 1999; Sillamaa and Veall, 2001; Gruber and Saez, 2002; Kopczuk, 2005; Weber, 2014; Burns and Ziliak, 2017) and for Scandinavia (e.g. Aarbu and Thoresen, 2001; Hansson, 2007; Blomquist and Selin, 2010; Holmlund and Soderstrom, 2011; Gelber, 2014; Kleven and Schultz, 2014; Thoresen and Vatto, 2015), but only a handful of studies for Continental Europe. Table A.1 in the appendix gives an overview of ETI studies. Studies for Anglo-Saxon countries typically find a relatively high ETI, with recent estimates suggesting a value for the elasticity of broad income of 0.29 (Burns and Ziliak, 2017) to 0.48 (Weber, 2014). Studies for Scandinavia typically find a relatively low ETI, with recent estimates suggesting a value of around 0.02-0.05 for the broad income elasticity in Norway (Thoresen and Vatto, 2015), 0.06 for Denmark (Kleven and Schultz, 2014) and 0.090.15 for Sweden (Gelber, 2014). Clearly, the deadweight loss of taxation is quite different for an ETI of 0.1 than for an ETI of 0.4. Hence, obtaining estimates for the ETI for countries in Continental Europe is of considerable importance. Lehmann et al. (2013) estimate an elasticity of broad income of 0.22 for France, using a reform targeted at lower incomes. Doerrenberg et al. (2017) estimate a broad income elasticity of 0.16-0.28 for Germany, using several reforms. Our base estimate of 0.24 for the Netherlands is in line with the findings for France and Germany. Hence, it appears that the elasticity of broad income in Continental European countries takes an intermediate position between Anglo-Saxon countries and Scandinavia. ${ }^{3}$

\footnotetext{
${ }^{2}$ An earlier version of this paper was published as a technical report (Jongen and Stoel, 2013).

${ }^{3}$ There is a related literature that studies the elasticity of taxable income using bunching around kinks and notches in the tax-benefit system (Saez, 2010; Kleven, 2016). Two recent studies for the Netherlands using the bunching methodology find rather low elasticities for taxable income, often
} 
Our second contribution is that we compare the elasticity of taxable labour income with the elasticity of (contractual) annual hours worked. Annual hours worked responses represent real distortions, whereas other tax base responses may only represent shifting behaviour with potentially large fiscal and other externalities. There are only a few studies that compare the two, information on hours worked is typically lacking in tax return data. ${ }^{4}$ Moffitt and Wilhelm (2000) report a substantial elasticity of broad income for high-income earners in the US, but do not find an increase in reported hours of work. In a recent study, Thoresen and Vatto (2015) find a small but positive and significant hours worked elasticity for wage earners in Norway of $0.04-0.05$, which is very close to their estimated broad income elasticity of $0.02-0.06$. We also find a positive significant (contractual annual) hours worked elasticity for wage earners in the Netherlands of 0.05 , but this elasticity is substantially lower than our estimated broad income elasticity of 0.21 for the sample for which we also have data on hours worked. Apparently, other mechanisms than hours worked seem to play a role in tax-base responses in the Netherlands, although part of the difference may still be due to changes in e.g. overtime hours.

Our third contribution is that we estimate the short- to medium- or longer-run taxable labour income elasticity, estimating the taxable labour income elasticity 1 year since the start of the reform (0.10 for the period 1999-2001), 3 years since the start of the reform ( 0.17 for the period 1999-2003) and 5 years since the start of the reform (0.24 for the period 1999-2005). ${ }^{5}$ We find that the elasticity is higher for longer horizons. ${ }^{6}$ Following Gruber and Saez (2002), it is common practice to use 3 -year intervals in the base specification. Our results suggest that this interval may be too short to capture the full tax-base responses to changes in marginal tax rates, and the same is true for hours-worked responses.

The outline of the paper is as follows. In Section 2 we consider the main features of the 2001 tax reform that we use as exogenous variation in the empirical analysis.

close to zero (Dekker et al., 2016; Bosch et al., 2019). However, estimates of taxable income using the bunching methodology are seriously attenuated by optimisation and other frictions, which may 'mask' much larger long-run elasticities (Chetty, 2012; Kleven, 2016).

${ }^{4}$ Indeed, Saez et al. (2012, p.38) argue that "[I]t would certainly be valuable to follow upon Moffitt and Wilhelm (2000) and systematically compare income reporting responses to tax changes with real economic responses such as labor supply or output."

${ }^{5}$ Using the same sample for the different horizons.

${ }^{6}$ Estimating the effect for all years, the full effect is realized 4 years after the reform. 
Section 3 outlines our empirical methodology. In Section 4 we discuss the data set and give some descriptive statistics. Section 5 gives the estimation results and a number of robustness checks. Section 6 discusses our findings and concludes.

\section{The 2001 tax reform}

In our empirical analysis we use data for the period 1999-2005. The 2001 tax reform in the Netherlands generates large exogenous variation in effective marginal tax rates. Table 1 shows the statutory tax bracket rates and the tax bracket lengths over the data period. In both the pre- and post-reform period there were four tax brackets. In 2000, the last year before the tax reform, the first bracket rate was $33.9 \%$, the second bracket rate was $37.95 \%$, the third bracket rate was $50 \%$ and the fourth (open) bracket rate was 60\%. In 2001, the first year of the reform, the rate in the first and second bracket dropped only slightly, to $32.35 \%$ and $37.60 \%$ respectively, and then increased somewhat in subsequent years. The third and fourth bracket rates dropped by 8 percentage points to $42 \%$ and $52 \%$, respectively. However, there were also important shifts in bracket lengths. The first and the second bracket became longer, reducing marginal tax rates for individuals that moved to a lower tax bracket. The third tax bracket became shorter, which moved part of the individuals that were in the third tax bracket to the fourth tax bracket, which meant a slight increase in the marginal tax rate from 50 to $52 \%$ for this group. ${ }^{7}$

Next to changes in bracket rates and bracket lenghts, another important driver of changes in effective marginal tax rates was the substantial increase in the (general) earned income tax credit (Arbeidskorting) in 2001. This earned income tax credit was phased in up to 16,000 euro in $2001 .^{8}$ This led to a significant drop in effective marginal tax rates for low incomes. Furthermore, the change from tax allowances (the benefit of which does depend on marginal tax rates) to tax credits (the benefit of which does not depend on marginal tax rates) creates additional variation in

\footnotetext{
${ }^{7}$ In the years after 2001, the top of the third bracket moved up again, but not in real terms, as this was simply the result of indexing the bracket lenghts with wage growth, and the same holds for the other tax brackets.

${ }^{8}$ In 2001, the gross annual minimum wage was 15,130 euro. In the period we consider, the earned income tax credit in the Netherlands had a phase-in range, but there was no phase-out, as opposed to e.g. the EITC in the US.
} 
Figure 1: Change in synthetic marginal tax rate by income (singles): 1999-2001

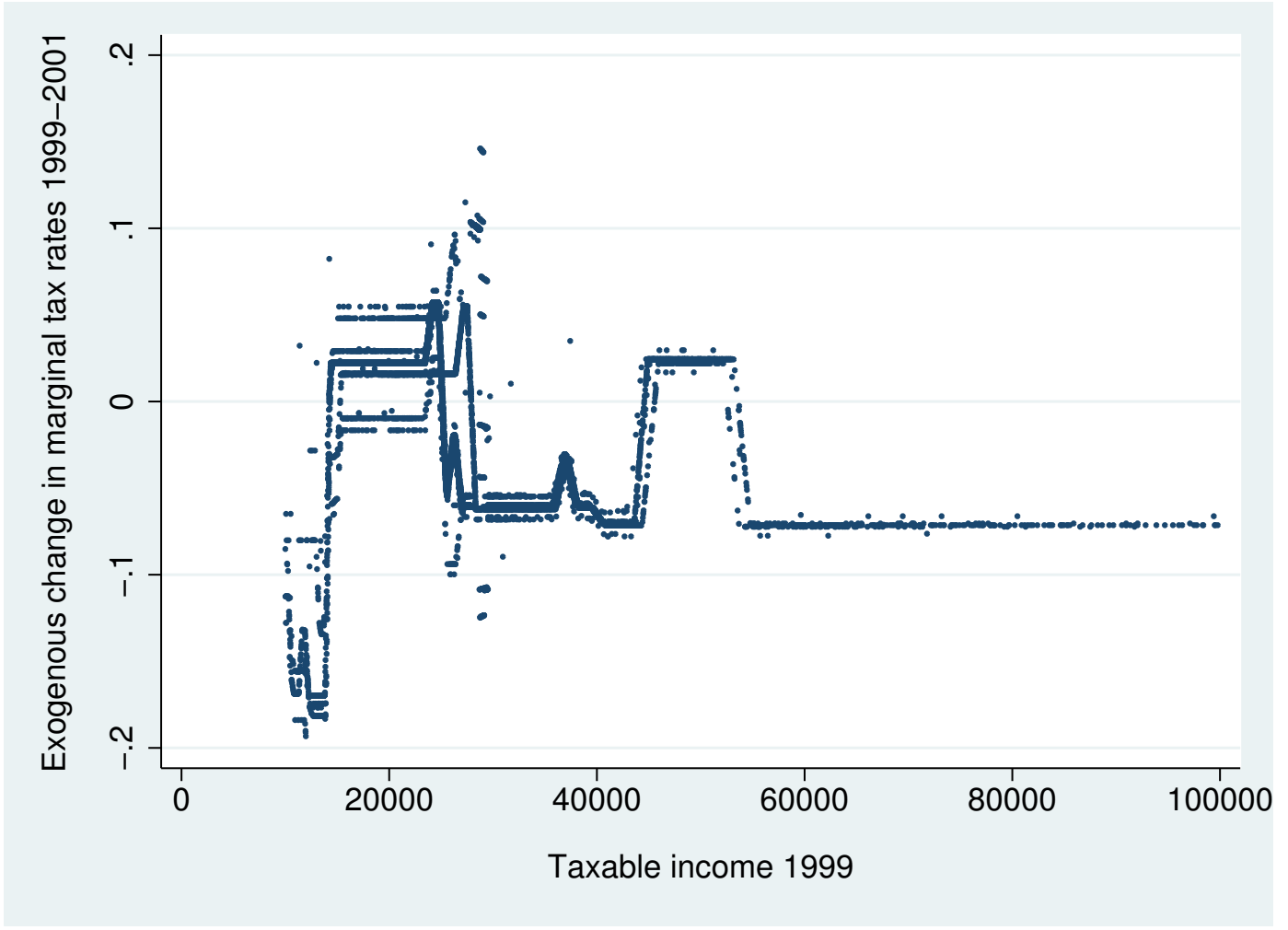

Source: Own calculations using the Labour Market Panel (Statistics Netherlands).

effective marginal tax rates in the lower part of the income distribution.

Figure 1 illustrates the changes in effective marginal tax rates. In this figure we plot the change in effective marginal tax rates from 1999 to 2001 (for 2001 we use synthetic marginal tax rates ${ }^{9}$ ) against income in year 1999. From Table 1 it is clear that the tax reform of 2001 reduced marginal tax rates for large parts of the income distribution. However, also for large parts of the income distribution there were hardly any changes. In particular, a large part of individuals in the second tax bracket experiences hardly any change, and also individuals that were shifted from the third to the fourth tax bracket hardly experienced any change. These groups serve as control groups in the empirical analysis.

Table 1 also makes clear that there was basically one major change in marginal

\footnotetext{
${ }^{9}$ Synthetic effective marginal tax rates are calculated on base year income projected forward with the average income growth. More on this in Section 3 where we discuss the empirical methodology.
} 
Table 1: Changes in the tax system: 1999-2005

\begin{tabular}{lccccccc}
\hline \hline & \multicolumn{2}{c}{ Pre reform } & \multicolumn{5}{c}{ Post reform } \\
& 1999 & 2000 & 2001 & 2002 & 2003 & 2004 & 2005 \\
\hline Bracket rates (in \%) & & & & & & & \\
& & & & & & & \\
Income bracket 1 & 35.75 & 33.90 & 32.35 & 32.35 & 32.35 & 33.40 & 34.40 \\
Income bracket 2 & 37.05 & 37.95 & 37.60 & 37.85 & 37.85 & 40.35 & 41.95 \\
Income bracket 3 & 50.00 & 50.00 & 42.00 & 42.00 & 42.00 & 42.00 & 42.00 \\
Income bracket 4 & 60.00 & 60.00 & 52.00 & 52.00 & 52.00 & 52.00 & 52.00
\end{tabular}

Bracket lengths (in $€$ )

$\begin{array}{lrrrrrrr}\text { Income bracket 1 } & 6,807 & 6,922 & 14,870 & 15,331 & 15,883 & 16,265 & 16,893 \\ \text { Income bracket 2 } & 21,861 & 22,233 & 27,009 & 27,847 & 28,850 & 29,543 & 30,357 \\ \text { Income bracket 3 } & 48,080 & 48,898 & 46,309 & 47,745 & 49,464 & 50,652 & 51,762 \\ \text { Income bracket 4 } & \infty & \infty & \infty & \infty & \infty & \infty & \infty\end{array}$

Income tax allowances and credits $^{a}($ maximum in $€)$

$\begin{array}{lrrrrrrr}\text { General allowance } & 3,993 & 4,061 & - & - & - & - & - \\ \text { General credit } & - & - & 1,576 & 1,647 & 1,766 & 1,825 & 1,894 \\ \text { Single parent allowance }^{b} & 3,042 & 3,094 & - & - & - & - & - \\ \text { Single parent credit }^{b} & - & - & 1,261 & 1,301 & 1,348 & 1,381 & 1,401\end{array}$

Earned income tax allowances and credits (maximum in $€$ )

\begin{tabular}{lrrrrrrr} 
General allowance $^{c}$ & 1,440 & 1,605 & - & - & - & - & - \\
General credit $^{d}$ & - & - & 920 & 949 & 1,104 & 1,213 & 1,287 \\
Single parent allowance $^{e}$ & 3,042 & 3,094 & - & - & - & - & - \\
Single parent credit $^{f}$ & - & - & 1,261 & 1,301 & 1,348 & 1,381 & 1,401 \\
Parent credit $^{g}$ & - & - & 138 & 190 & 214 & 224 & 228 \\
Additional parent credit $^{h}$ & - & - & - & - & - & - & 389 \\
\hline
\end{tabular}

${ }^{a}$ Tax allowances reduce taxable income (the financial gain depends on the marginal tax rate), tax credits reduce the amount of taxes paid (the financial gain does not depend on the marginal tax rate). ${ }^{b}$ Single parent with a dependent child $<27$ years of age. ${ }^{c}$ Maximum tax allowance for working individuals. The tax allowance is $12 \%$ of gross earned income, up to the maximum. ${ }^{d}$ Maximum tax credit for working individuals. The phase-in rate is (approximately) $1.7 \%$ up to $50 \%$ of the annual minimum wage, and $11 \%$ of gross earned income beyond $50 \%$ of the annual minimum wage, up to the maximum. ${ }^{e}$ Maximum tax allowance for working single parents with a dependent child $<12$ years of age. The tax allowance is $12 \%$ of gross earned income, up to the maximum. $f_{\text {Maximum tax }}$ credit for working single parents with a dependent child $<12$ years of age in the year 2001 and $<16$ years of age in the years beyond 2002. The tax credit is $4.3 \%$ of gross earned income, up to the maximum. ${ }^{g}$ Tax credit for working parents with a dependent child $<12$ years of age. The tax credit is independent of gross earned income, provided gross earned income exceeds (approximately) $25 \%$ of the annual minimum wage. ${ }^{h}$ Tax credit for working single parents and secondary earners with a dependent child $<12$ years of age. The tax credit is independent of gross earned income, provided gross earned income exceeds (approximately) 25\% of the annual minimum wage. 
Figure 2: Histograms of year-on-year changes in marginal tax rates

(a) 1999-2000

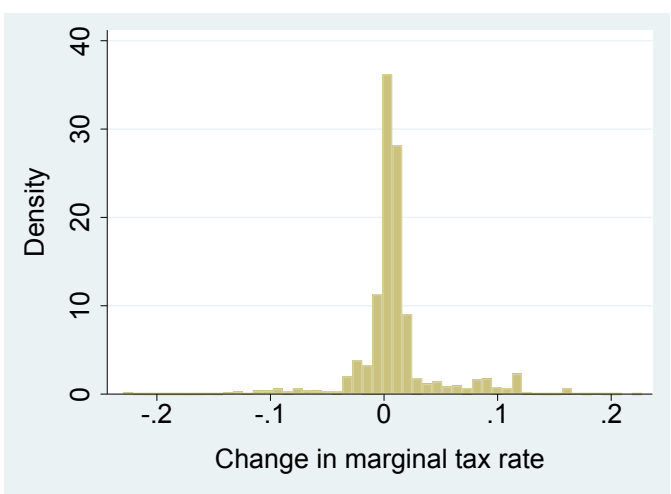

(c) 2001-2002

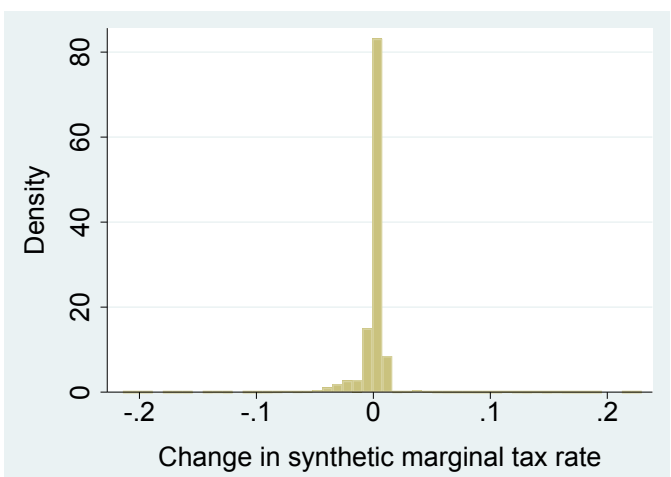

(e) 2003-2004

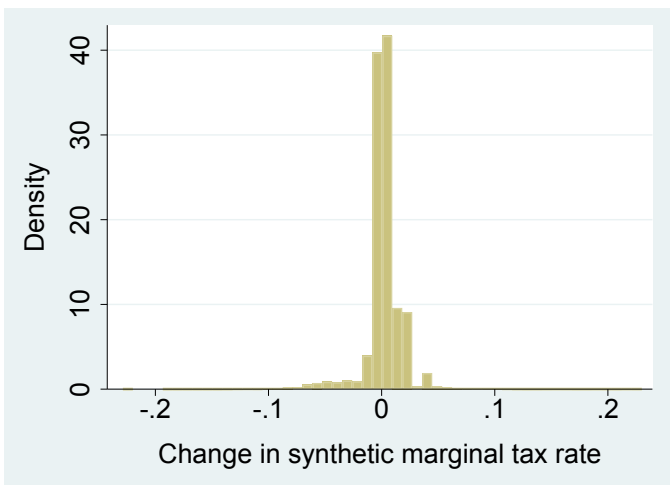

(b) 2000-2001

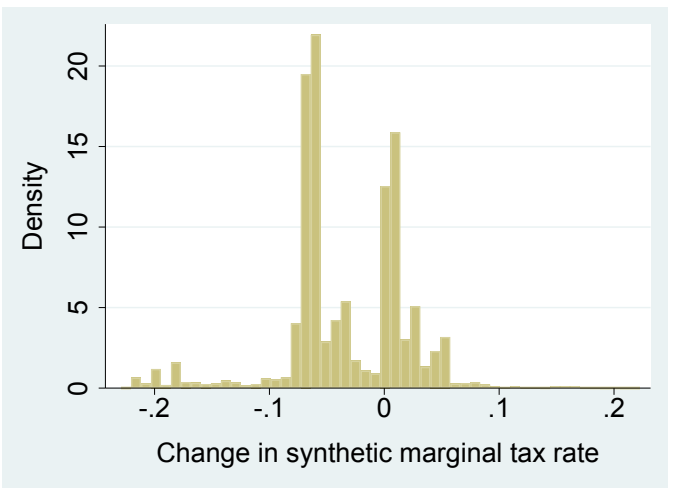

(d) 2002-2003

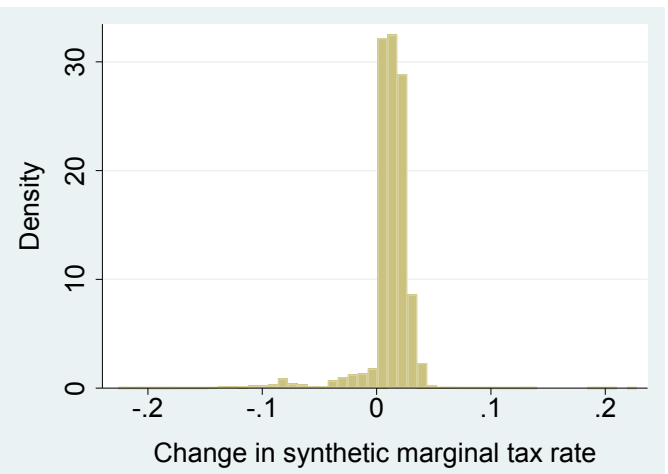

(f) $2004-2005$

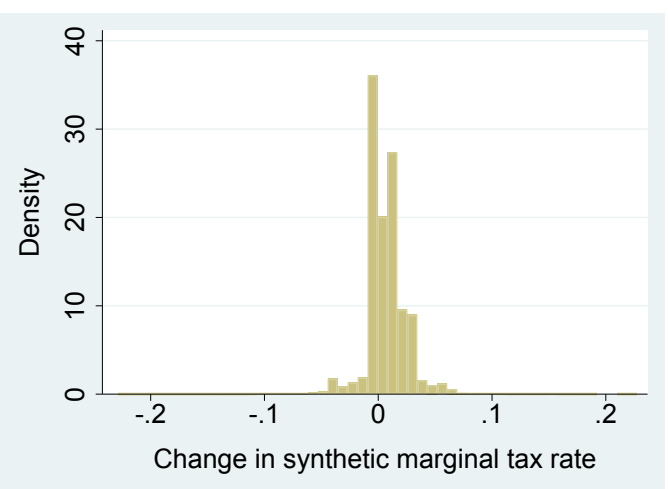

Source: Own calculations using the Labour Market Panel (Statistics Netherlands). 
tax rates in our data period. After 2001, tax rates and tax brackets remained rather stable, at least up to 2005. This can also be seen in Figure 2, which shows a histogram of year-on-year changes in effective marginal tax rates for our data set. We see that for all year-on-year changes except 2000-2001 most individuals experienced hardly any change in the effective marginal tax rate (of course incomes and hence marginal tax rates do change for some individuals), whereas in 2000-2001 there is a clear second spike around -8\%-points and also some smaller spikes of individuals that experience a more modest decrease or increase in effective marginal tax rates.

\section{$3 \quad$ Empirical methodology}

Following Auten and Carroll (1999), Gruber and Saez (2002) and Kleven and Schultz (2014), our base specification reads: ${ }^{10}$

$$
\log \left(\frac{E_{i, t+s}}{E_{i, t}}\right)=\beta_{0}+\beta_{1} \log \left(\frac{1-T_{i, t+s}^{\prime}\left(E_{i, t+s}\right)}{1-T_{i, t}^{\prime}\left(E_{i, t}\right)}\right)+X_{i, t} \beta_{2, x}+\beta_{3} \log \left(E_{i, t}\right)+\varepsilon_{i} .
$$

In this regression, $E_{i, t}\left(E_{i, t+s}\right)$ denotes taxable labour income of individual $i$ in year $t(t+s), 1-T_{i, t}^{\prime}().\left(1-T_{i, t+s}^{\prime}().\right)$ is the net-of-tax rate of individual $i$ in year $t(t+s)$, $X_{i t}$ are additional control variables (demographic dummies and sector dummies), measured in the base year $t$, and $\varepsilon_{i}$ is the error term. ${ }^{11,12}$ We estimate the elasticity of taxable income for different horizons $s$, allowing for a difference between shortand medium-run effects. Specifically, we estimate differences for $s$ equal to 2 years (1999-2001), 4 years (1999-2003) and 6 years (1999-2005). $\beta_{1}$ is our main parameter of interest, the elasticity of taxable labour income with respect to the net-of-tax rate.

There are a number of concerns that we need to address in our empirical analysis. First, the marginal tax rate is endogenous. In a progressive tax system, a higher income leads to a higher marginal tax rate when the individual moves to a higher tax bracket. This creates a relationship between the error term and the net-of-tax rate and therefore to biased estimates. Following Auten and Carroll (1999) we deal

\footnotetext{
${ }^{10}$ We do not control for income effects, as we do not have information on unearned income, as opposed to e.g. Gruber and Saez (2002) and Kleven and Schultz (2014).

${ }^{11}$ In all regressions we report heteroscedasticity robust standard errors, and we weight observations by base year income and by the population weights in the data set.

${ }^{12}$ When we estimate the elasticity of taxable labour income for one spouse, we take the income of the other spouse as given.
} 
with this problem by using synthetic net-of-tax rates as an instrument for actual netof-tax rates. Specifically, we project income forward using average income growth, and calculate synthetic marginal tax rates using this projected income which reflects the income in the absence of behavioural changes. We then estimate equation (1) using two-stage least squares with the synthetic net-of-tax rates as an instrument for actual net-of-tax tax rates. ${ }^{13}$ In the empirical analysis this instrument is always very strong (available on request). ${ }^{14}$

Another concern is mean reversion in income growth. Individuals that experience a positive shock in income in one period are more likely to have lower subsequent income growth than individuals that do not have a positive shock to income, and vice versa for individuals that experience a negative income shock. This leads to mean reversion in incomes. When the reform targets mostly low- or high-wage earners this may again lead to a bias in the estimates, also when we use synthetic marginal tax rates. Again following Auten and Carroll (1999), we control for mean reversion by including log base-year income in the explanatory variables. We expect this variable to have a negative sign, so that ceteris paribus individuals with a higher base year income will have lower subsequent income growth. The results show that it is important to control for mean reversion, in line with the findings of Kleven and Schultz (2014).

A further concern, emphasized by Kopczuk (2012), is that the dynamics of mean reversion may be different for the treatment group (with substantial changes in effective marginal tax rates) and control group (with minor changes in effective marginal tax rates). In the data section we provide graphical evidence for the prereform period that shows that these dynamics are not that different for our treatment and control group.

Yet another concern is that we need to control for other exogenous changes in income. Indeed, skill-biased technological change or globalisation may cause the

\footnotetext{
${ }^{13}$ The first-stage equation reads: $\log \left(\frac{1-T_{i, t+s}^{\prime}\left(E_{i, t+s}\right)}{1-T_{i, t}^{\prime}\left(E_{i, t}\right)}\right)=\gamma_{0}+\gamma_{1} \log \left(\frac{1-T_{i, t+s}^{\prime s y n t h e t i c}\left(E_{i, t+s}^{\text {synthetic }}\right)}{1-T_{i, t}^{\prime}\left(E_{i, t}\right)}\right)+X_{i, t} \gamma_{2, x}+\gamma_{3} \log \left(E_{i, t}\right)+\epsilon_{i}$, where $T_{i, t+s}^{\text {ssythetic }}($.$) is the synthetic effective marginal tax rate corresponding to the synthetic$ income $E_{i, t+s}^{\text {synthetic }}$ in period $t+s$.

${ }^{14}$ Ideally, we would also have used lags of base-year income for the instrument, as suggested by Weber (2014). However, we do not have enough pre-reform years to apply this methodology.
} 
Figure 3: Top primary income shares in the Netherlands: Income Panel

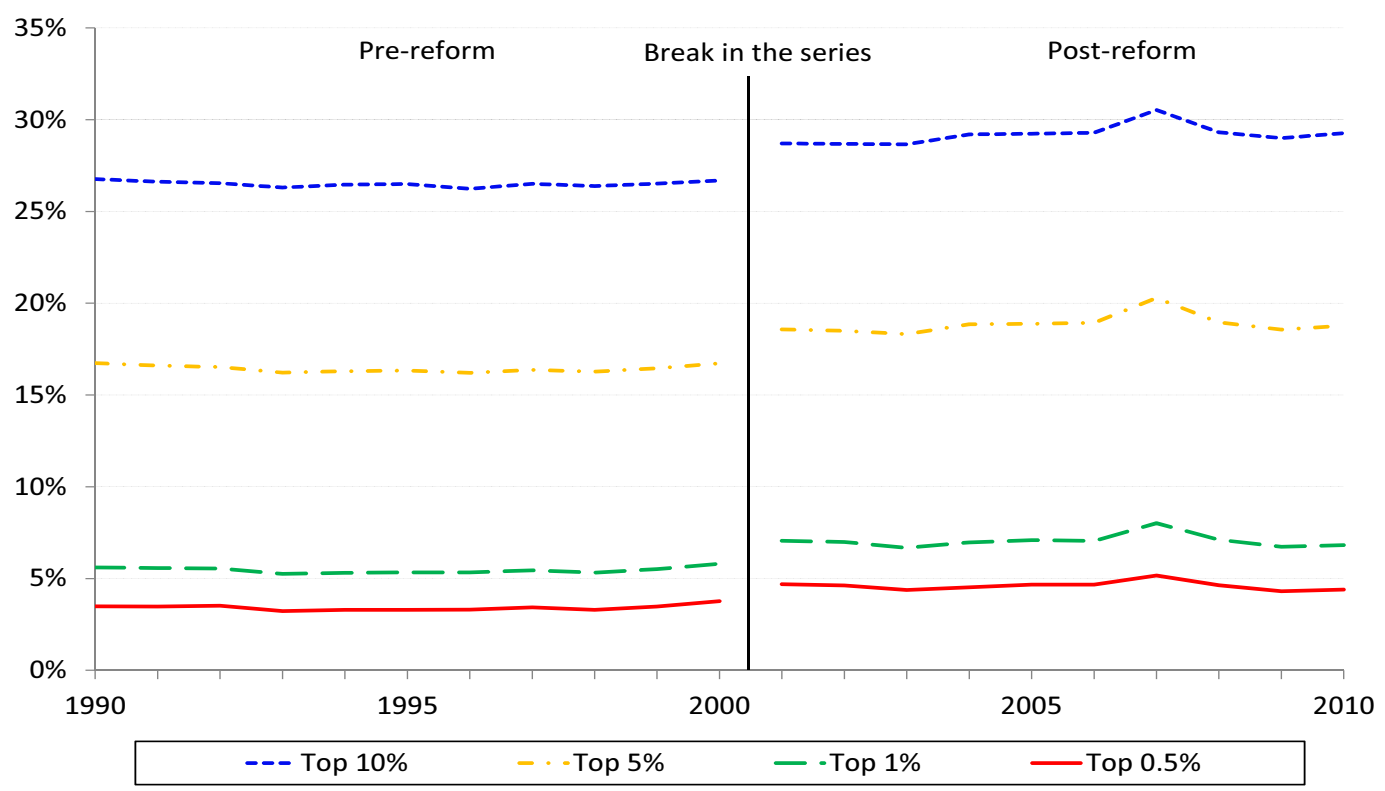

Source: Jacobs et al. (2013). Data set: Income Panel (Inkomenspanelonderzoek) (remote access version with uncensored top incomes) of Statistics Netherlands. The income shares are for 'primary income', the sum of wage and profit income, per individual. There is a break in the series in 2001 (as the definition of income changed). Additional income components (in particular one-off payments like severance pay) were included, and some income components were obtained from other data sources than before (see Knoef, 2011, for an overview of the most important changes).

Figure 4: Top wage income shares in the Netherlands: Labour Market Panel

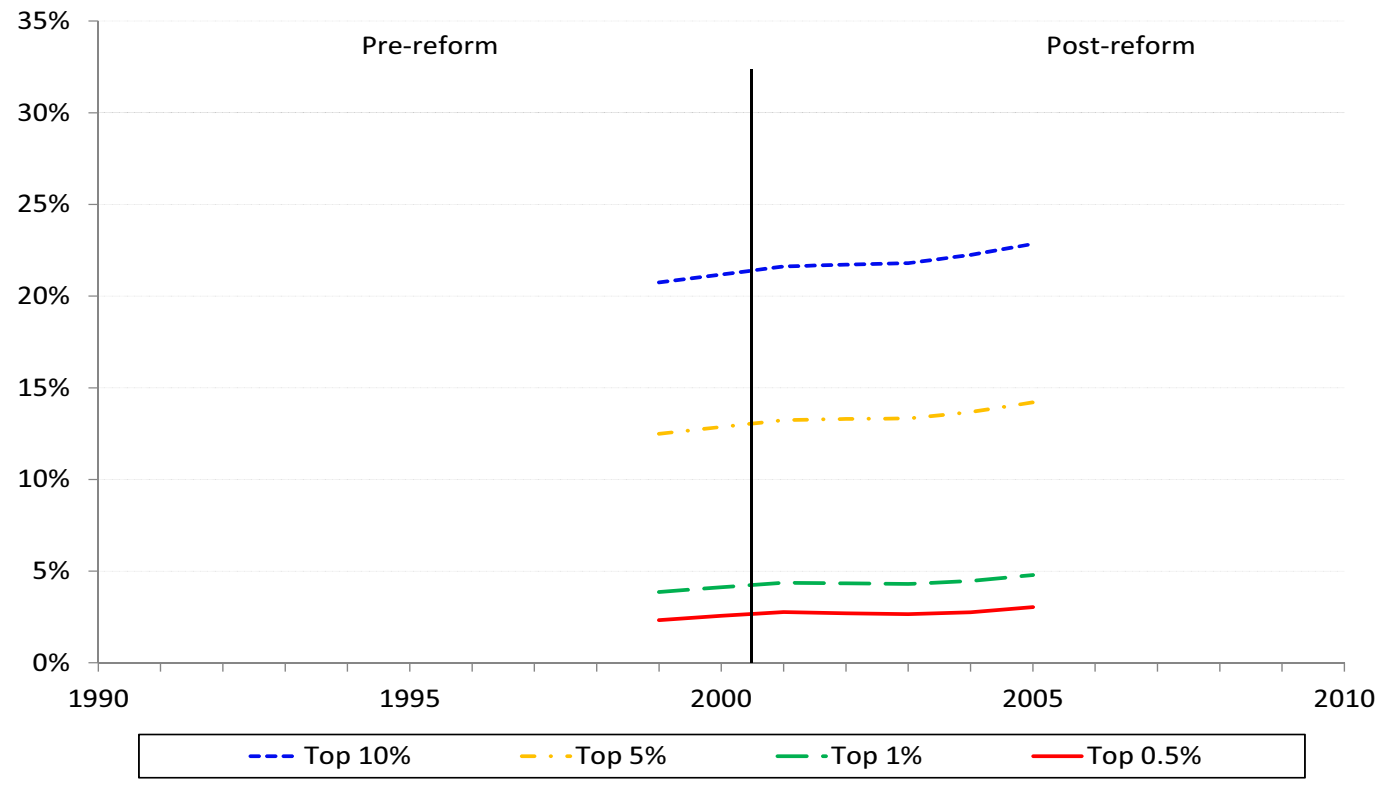

Source: Own calculations using the Labour Market Panel (Arbeidsmarktpanel) (uncensored wage income) of Statistics Netherlands. The income shares are for wage income per individual. There is no break in the wage income series. 
incomes of high-wage earners to rise faster than low-wage earners. If the reform targets high-wage earners we run the risk of confounding the treatment effect of the change in tax rates with differential trends for different income groups. We believe that this is less of a concern in our case. First, the income distribution was relatively stable over the decade before the reform, similar to the case of Denmark studied in Kleven and Schultz (2014). Figure 3 shows that the income shares of the top 10, 5, 1 and $0.5 \%$ of the income distribution were very stable in the decade before the 2001 reform. Furthermore, Afman (2006, Table 1) shows that the same is true for all income deciles. ${ }^{15}$ Figure 3 suggests some increase in top income shares after the 2001 reform, but a break in the series, due to a change in the definition of income, makes it hard to infer the effect of the 2001 reform. Figure 4 shows the top wage income shares in our data set, there is no break in this series but the data period is much shorter. These data suggest an increase in the top incomes shares following the reform. Second, also similar to Kleven and Schultz (2014), we study a reform that led to significant changes in marginal tax rates for different groups of the income distribution, not just high-wage earners but also low- and middle-wage earners and within some income groups we have both positive and negative changes (see Figure 1). Third, similar to Kleven and Schultz (2014) we have a data set that includes socioeconomic variables that allow us to control for differential trends for individuals with different socioeconomic characteristics like the level of education and ethnicity. ${ }^{16}$ However, as a robustness check we also consider the solution to differential trends offered by Gruber and Saez (2002) who control for differential trends across the income distribution by including a spline in log base-year income. These splines can be used to control for mean reversion and for different income growth across income groups, such as skill-biased technological change. However, an issue with this method is that the coefficients of the splines could 'soak up' not only exogenous growth differentials but also the identifying variation of the tax reform. Keeping this concern in mind, we also present results using a 5-piece spline in log base-year income, dividing income groups in quintiles. ${ }^{17}$ The splines are added

\footnotetext{
${ }^{15}$ This does not mean that individual incomes are stable, indeed mean reversion at the individual level is important to take into account, as we show in the Results section.

${ }^{16}$ Furthermore, we also include a dummy for the (pre-reform) sector in which the individual is working to allow for sector-specific wage growth.

${ }^{17}$ We have also estimated models with up to 10-piece splines in log base-year income (available on request). However, the coefficients on the splines are then estimated with rather large standard
} 
as variables to the regression and the coefficients capture quintile specific income growth.

\section{Data}

We use data from the Labour Market Panel (Arbeidsmarktpanel) of Statistics Netherlands (2009). The Labour Market Panel is a rich and large administrative household panel data set, starting in 1999. We have data for the period 1999-2005. This data set combines administrative data on taxable labour income from the Tax Office with administrative demographic individual and household information from municipalities (Gemeentelijke Basisadministratie), administrative data on contractual annual hours worked and the sector in which the individual is working (main occupation) from the Social Statistical Panel (Sociaal Statistisch Bestand) and survey data on education from the Labour Force Survey (Enquete Beroepsbevolking).

From this data set we select employees aged 20-55 in 1999, that earn more than 10 thousand euro in 1999, that have no income from social insurance benefits (e.g. disability, unemployment, welfare or early retirement benefits), and that do not change between the states of single, single parent or part of a couple over the whole period of 1999-2005. We make these selections to limit problems of mean reversion and to remove big changes in marginal tax rates and income that are not linked to the tax reform. Furthermore, we do not have information on personal deductions in our data set. This creates measurement error in the net-of-tax rates, since we have an imprecise measure of taxable income, and hence also in the change in the net-of-tax rates. ${ }^{18}$ To mitigate this problem, we drop individuals whose marginal tax rate changes by more than 30 percent, which are unrelated to the reform and more importantly are likely to contain substantial measurement error. ${ }^{19}$ After these

errors, which yields unstable results for the elasticity of taxable labour income.

${ }^{18}$ For example, the steep phase-out of some income-dependent subsidies, like housing subsidies, creates very large effective marginal tax rates. When the relevant income variable is measured with error, we falsely predict large changes in effective marginal tax rates over time, which leads to a downward bias in our estimates because part of the treatment group actually does not experience a large change in the effective marginal tax rate whereas part of the control actually does experience a large change in the effective marginal tax rate.

${ }^{19}$ Specifically, we restrict the sample to individuals with an absolute change in the log of the net-of-tax rate less or equal to .3. Table A.4 in the appendix shows that the estimated elasticities 
Table 2: Descriptive statistics base year

\begin{tabular}{lrr}
\hline \hline & Mean & SD \\
\hline Taxable labour income 1999 & 30,573 & 15,643 \\
Net-of-tax rate & 0.505 & 0.057 \\
Age & 39.709 & 7.974 \\
Male & 0.674 & 0.469 \\
Female & 0.326 & 0.469 \\
Primary education (BO) & 0.043 & 0.203 \\
Lower secondary education (VMBO) & 0.167 & 0.373 \\
Higher secondary education (MBO, HAVO, VWO) & 0.449 & 0.497 \\
Tertiary education (HBO, WO) & 0.342 & 0.474 \\
Native & 0.898 & 0.303 \\
Western immigrant & 0.029 & 0.167 \\
Non-Western immigrant & 0.074 & 0.261 \\
Married couple with children & 0.564 & 0.496 \\
Married couple without children & 0.155 & 0.321 \\
Unmarried couple with children & 0.032 & 0.175 \\
Unmarried couple without children & 0.117 & 0.321 \\
Single & 0.114 & 0.318 \\
Single parent & 0.018 & 0.134 \\
\hline Observations & 160,601 & \\
\hline \hline
\end{tabular}

Notes: Dutch abbreviations of education levels in brackets.

selections are made we are left with 160,601 observations for the regressions.

Descriptive statistics of the estimation sample are given in Table 2. Mean taxable labour income in 1999 is 30,573 euro. For the socioeconomic characteristics we use the data for the base year 1999. Individuals in our sample are on average 39.7 years old. $67 \%$ of individuals in our sample are men (due to the selections). Most of the individuals have higher secondary education (45\%) or tertiary education (34\%), a small minority has only primary education $(4 \%)$ and some more individuals have lower secondary education (17\%). Regarding ethnicity, $90 \%$ is native Dutch, $3 \%$ is Western immigrant and $7 \%$ is Non-Western immigrant. Looking at household composition, most individuals are in a married couple with children (56\%). The second largest category is individuals in a married couple without children (16\%).

are indeed somewhat smaller when we include the observations with bigger changes in effective marginal tax rates, consistent with classical measurement error. 
The shares of singles and individuals in unmarried couples without children are $11 \%$ and $12 \%$, respectively, and the shares of individuals in unmarried couples with children $(3 \%)$ and single parents $(2 \%)$ are small.

We use the official tax-benefit calculator MIMOS-2 of CPB Netherlands Bureau for Economic Policy Analysis for the 1999-2005 period to calculate effective marginal tax rates. MIMOS-2 is a tax-benefit calculator that contains a detailed programming of the tax-benefit system in the Netherlands, including all income dependent subsidies and tax credits. We determine effective marginal tax rates by increasing all gross incomes by 3 percent. ${ }^{20}$ Effective marginal tax rates are then calculated as the change in gross income minus the change in disposable income over the change in gross income.

Synthetic effective marginal tax rates are calculated for synthetic income. We use the growth of average taxable labour income in our selection to project synthetic income forward out of 1999. In the regressions we use the change in real taxable labour income in 1999 euro, incomes from later years are deflated with the CPI.

Following Weber (2014, Figure 1), Figure 5 gives a semi-parametric representation of the relation between the outcome variable (the growth in taxable labour income) and the instrument (the predicted change in the log marginal net-of-tax rate). ${ }^{21}$ The dashed lines give the $95 \%$ confidence interval. There is a positive relationship between the instrument and the outcome variable, with some 'flattening' of the relation close to zero. ${ }^{22}$

Again following Weber (2014, Figure 2), Figure 6 gives a graphical representation of the first-stage of the regressions, the relation between the predicted log of the marginal net-of-tax rate change and the actual log of the marginal net-of-tax rate change. The relation is very strong for the most part. Only at the upper tail the relationship weakens and even seems to reverse, but there are only a few observations there.

Finally, following Kopczuk (2012, Figure 20), Figure 7 plots the growth in taxable

\footnotetext{
${ }^{20}$ The Netherlands has an individual tax system where some subsidies and tax credits depend on household income. For couples we calculate the effective marginal tax rate for each partner separately, keeping the income of the other partner fixed.

${ }^{21}$ Using the lpolyci command in Stata, with a third-order polynomial and a bandwidth parameter of 0.16, following Burns and Ziliak (2017).

${ }^{22}$ Other papers that present similar plots show a similar flattening of the relation close to zero (e.g. Weber, 2014; Burns and Ziliak, 2017; Doerrenberg et al., 2017).
} 
Figure 5: Semi-parametric relation instrument and taxable labour income

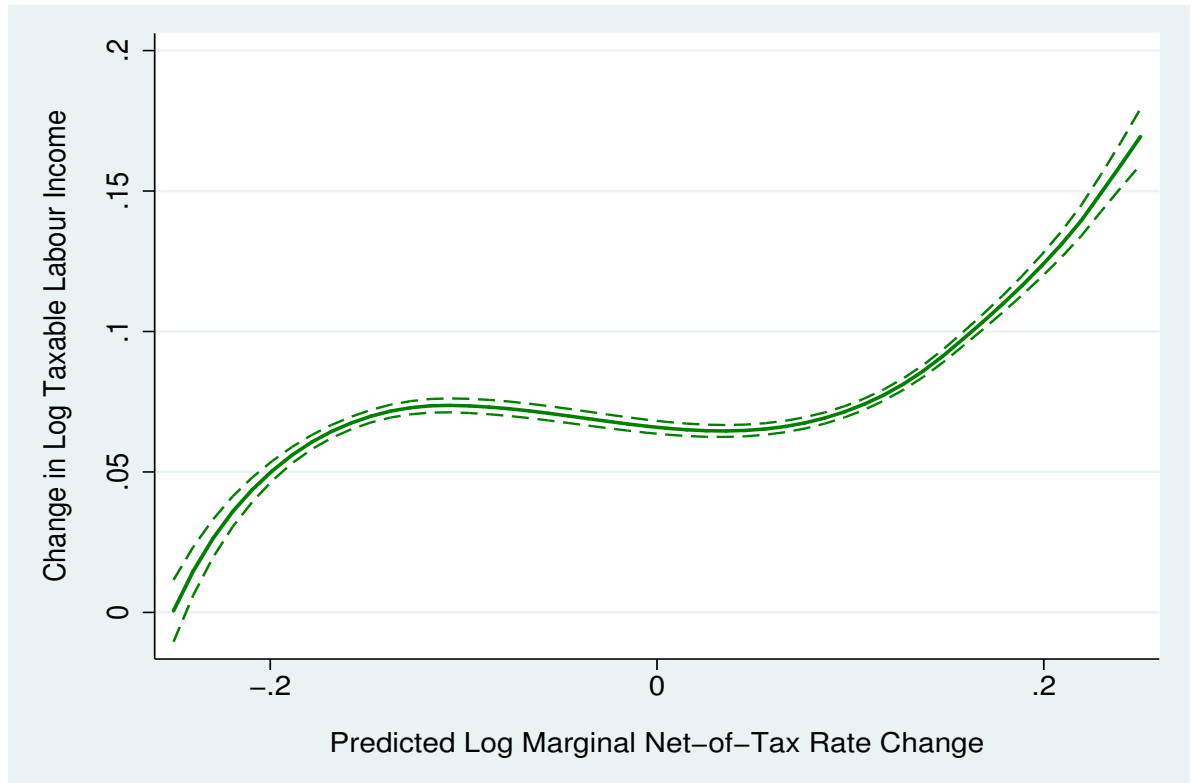

Source: Own calculations using the Labour Market Panel (Statistics Netherlands).

Figure 6: Strength of the instrument

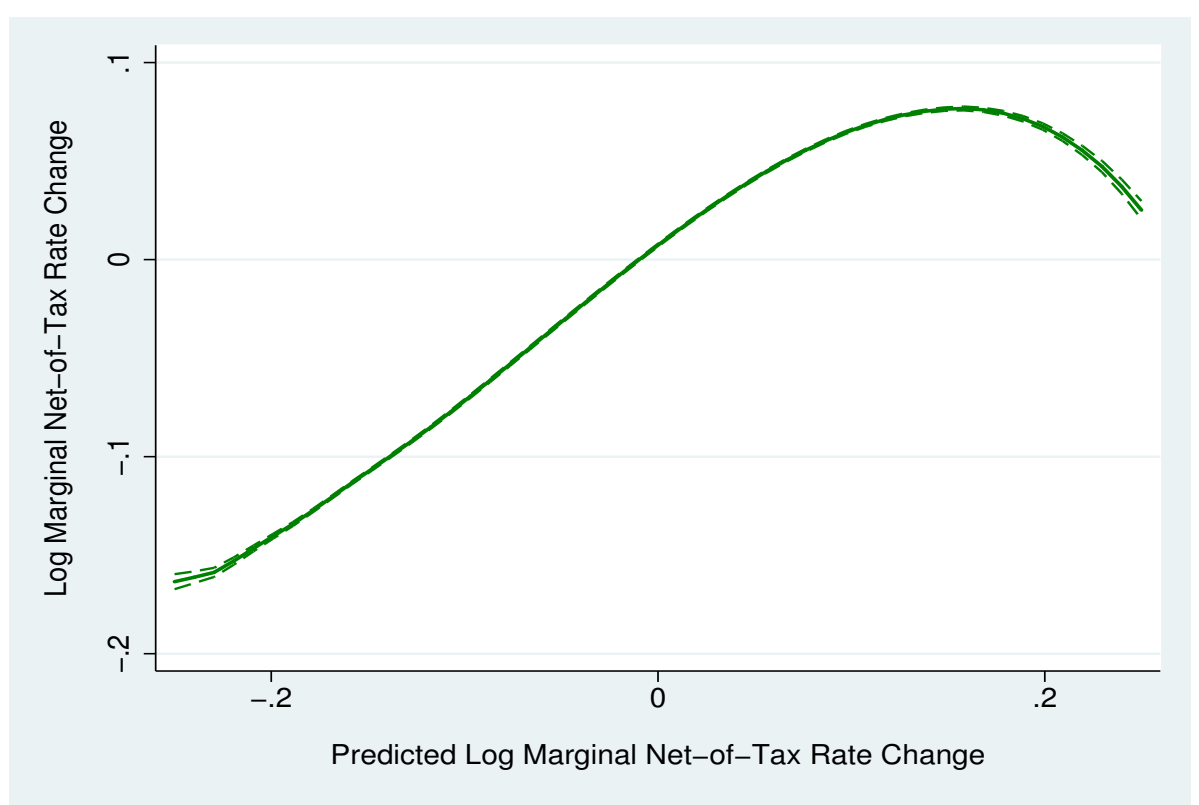

Source: Own calculations using the Labour Market Panel (Statistics Netherlands). 
Figure 7: Pre-reform mean reversion treatment (green) and control group (gold)

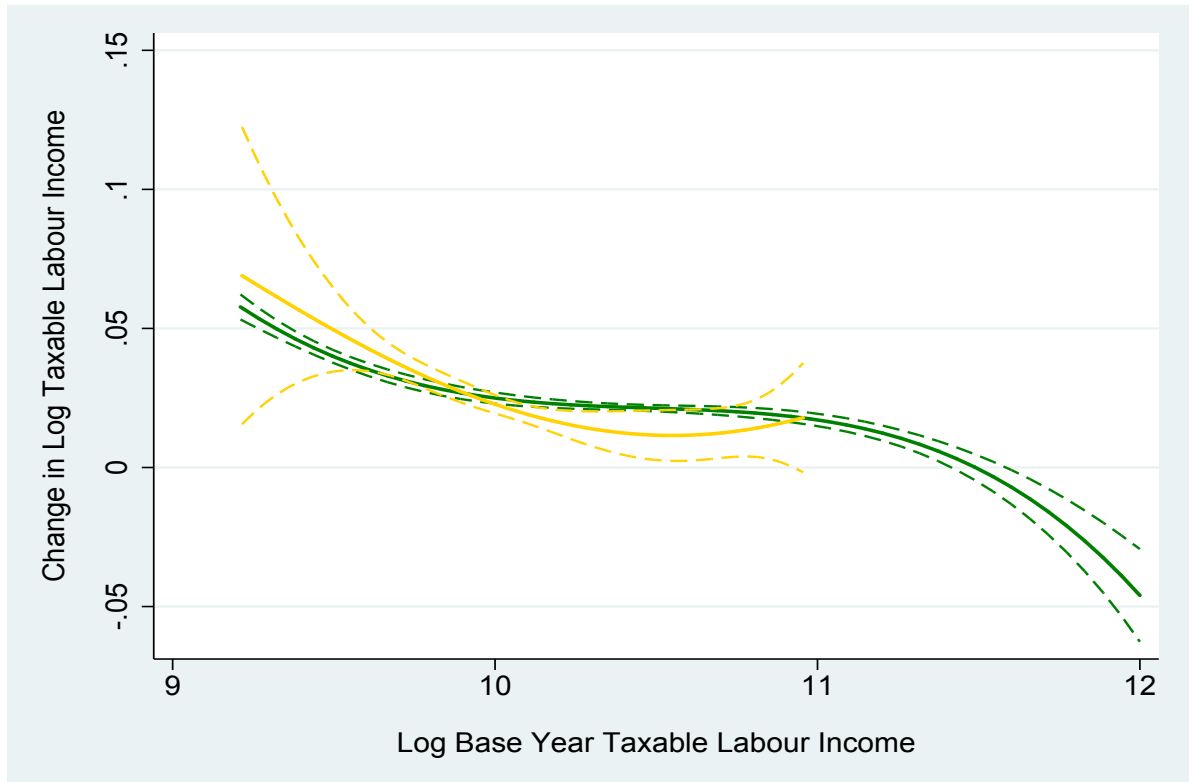

Source: Own calculations using the Labour Market Panel (Statistics Netherlands).

labour income in the pre-reform period 1999-2000 against the level of taxable labour income in 1999, separately for the treatment group (decrease in effective marginal tax rate) and the control group (no decrease or increase in effective marginal tax rate). Note that there are no individuals in the control group (yellow lines) for the highest incomes, since the reform reduced the top marginal tax rate. We see that for the income segment for which the treatment and control group overlap, the growth in taxable labour income is quite similar, although it appears a bit lower (higher) for the treatment group below (above) 22 thousand euro (log of 10). Furthermore, the relation is negative, as we would expect in the case of mean reversion.

\section{Results}

Table 3 gives the base results for all workers. We show three different specifications, one with no pre-reform income controls, one with log base-year income to control for mean reversion and one with a 5-piece spline in log base-year income to control for mean reversion and other remaining differential trends in exogenous income growth. In all regressions we include socioeconomic controls and dummies for the sector in 
Table 3: Base results: all workers

\begin{tabular}{lccc}
\hline \hline & $(1)$ & $(2)$ & $(3)$ \\
Period & $1999-2001$ & $1999-2003$ & $1999-2005$ \\
\hline No pre-reform income & $-0.0188^{*}$ & $0.0209^{*}$ & $0.0648^{* * *}$ \\
control & $(0.0101)$ & $(0.0112)$ & $(0.0129)$ \\
& & & \\
Log base-year income & $0.0970^{* * *}$ & $0.1657^{* * *}$ & $0.2415^{* * *}$ \\
& $(0.0090)$ & $(0.0108)$ & $(0.0143)$ \\
& & & \\
5-piece spline in log & $0.0754^{*}$ & $0.1681^{* * *}$ & $0.2226^{* * *}$ \\
base-year income & $(0.0385)$ & $(0.0339)$ & $(0.0356)$ \\
\hline Observations & 160,601 & 160,601 & 160,601 \\
\hline \hline
\end{tabular}

Notes: Heteroscedasticity robust standard errors in parentheses, $* * * \mathrm{p}<0.01$, ** $\mathrm{p}<0.05, * \mathrm{p}<0.1$. Observations are weighted by population weights and 1999 income. Base specification projecting synthetic incomes out of 1999 and using socioeconomic individual and household characteristics and sector dummies for 1999. Sample is restricted to individuals with labour income $>10,000$ euro in 1999. Full estimation results for the specification with log base-year income as the income control can be found in Table A.2 in the appendix.

which the individual is working (all measured in 1999).

Not controlling for base-year income we find small, and even negative, ETIs, in line with the findings of Kleven and Schultz (2014). However, when we include log base-year income to control for mean reversion in income growth we find significant positive ETIs, again in line with the findings of Kleven and Schultz (2014). ${ }^{23}$ The elasticity rises from 0.10 in the short-run (1999-2001) to 0.24 for the medium to longer run (1999-2005) when we use log base-year income as a control. The rise in the ETI suggests that adjustment to the new marginal tax rates takes time. Since Gruber and Saez (2002), it is common practice to use 3-year intervals in the

\footnotetext{
${ }^{23}$ Full estimation results of the base specification can be found in Table A.2 in the appendix. The controls used in the regressions are typically significant and show that income growth decreases with age, increases with an individual's level of education, is higher for males than for females, is higher for individuals in households with children, and is slightly higher for immigrants than for natives. Log base-year income has a significant negative coefficient, indicating it is important to control for mean reversion.
} 
base specification (and present 1- or 2-year intervals as a robustness check). Our results suggest that this interval may be too short to capture the full tax base responses to changes in marginal tax rates. ${ }^{24}$ Finally, when using the 5-piece spline we find very similar results, indeed the parameter estimates are not statistically significantly different, the elasticity rises from 0.08 in the 1999-2001 period to 0.22 for the 1999-2005 period. The fact that we find similar results using log base-year income and using a spline in log base-year income is consistent with a stable income distribution. ${ }^{25,26}$

Table 4 shows that our results are robust to the income threshold. Specifically, when we select individuals with an income above 5,000 euro in 1999, instead of 10,000 euro in the baseline, we find similar elasticities. In particular, with our preferred specification with log base-year income as the income control, we now get an estimate of 0.23 , compared to 0.24 in the base sample. The results using the 5-piece spline are also very similar, 0.20 compared to 0.22 when using the base sample.

Table 5 shows that our results are also quite similar when we use 2000 as the base

\footnotetext{
${ }^{24}$ And the same is true for hours worked responses, see Table 8. Thoresen and Vatto (2015, Table B.4) also find that the elasticity of broad income and hours worked rises when they use longer intervals, also when they increase the interval length from 3 to 4 years. Estimating the effect for all years, we find that the full effect is realized 4 years after the reform (1999-2004), see Table A.3 in the appendix. Note that there are small differences with the base results for the period 1999-2001, 1999-2003 and 1999-2005, because now we only include observations whose (absolute) change in effective marginal tax rates is less than $30 \%$ in 2002 and 2004 as well.

${ }^{25}$ Table A.4 shows that we obtain somewhat lower estimates when we also include observations with bigger changes in effective marginal tax rates. However, as argued in the Data section, the additional observations are likely to be contaminated with measurement error. Indeed, the profile of estimates with different sample selections follows the pattern of classical measurement error, with the elasticity falling somewhat as we allow for bigger (absolute) changes in the effective marginal tax rates.

${ }^{26}$ In the base specification we weigh observations by taxable labour income (and population weights) because we are mostly interested in the elasticity of the tax base, not the elasticity of taxable labour income of the average person. When we do not weigh the observations by taxable labour income, we find an elasticity of taxable labour income of 0.21 not accounting for mean reversion, 0.27 when we include log base-year income and 0.22 when we include a 5-piece spline in $\log$ base-year income. The latter two are not that different from our base specification. However, the first one is much higher, indicating that mean reversion will bias the estimates mostly through mean reversion at relatively high incomes.
} 
Table 4: Robustness check: base year income $>5$ thousand euro

\begin{tabular}{lccc}
\hline \hline & $(1)$ & $(2)$ & $(3)$ \\
Period & $1999-2001$ & $1999-2003$ & $1999-2005$ \\
\hline $\begin{array}{l}\text { No pre-reform income } \\
\text { control }\end{array}$ & $-0.0168^{*}$ & $0.0233^{* *}$ & $0.0735^{* * *}$ \\
& $(0.0098)$ & $(0.0110)$ & $(0.0126)$ \\
Log base-year income & $0.0956^{* * *}$ & $0.1609^{* * *}$ & $0.2345^{* * *}$ \\
& $(0.0077)$ & $(0.0096)$ & $(0.0122)$ \\
& & & \\
5-piece spline in log & 0.0503 & $0.1521^{* * *}$ & $0.2047^{* * *}$ \\
base-year income & $(0.0394)$ & $(0.0348)$ & $(0.0365)$ \\
\hline Observations & 170,216 & 170,216 & 170,216 \\
\hline \hline
\end{tabular}

Notes: Heteroscedasticity robust standard errors in parentheses, ${ }^{* * *} \mathrm{p}<0.01,{ }^{* *} \mathrm{p}<0.05,{ }^{*}$ $\mathrm{p}<0.1$. Observations are weighted by population weights and 1999 income. Base specification projecting synthetic incomes out of 1999 and using socioeconomic individual and household characteristics and sector dummies for 1999. Sample is restricted to individuals with labour income $>5,000$ euro in 1999 .

Table 5: Robustness check: year 2000 as base year

\begin{tabular}{lccc}
\hline \hline & $(1)$ & $(2)$ & $(3)$ \\
Period & $2000-2001$ & $2000-2003$ & $2000-2005$ \\
\hline Log base-year income & $0.0412^{* * *}$ & $0.1002^{* * *}$ & $0.1812^{* * *}$ \\
& $(0.0115)$ & $(0.0191)$ & $(0.0241)$ \\
& & & \\
5-piece spline in log & 0.0326 & $0.1628^{* * *}$ & $0.2074^{* * *}$ \\
base-year income & $(0.0245)$ & $(0.0338)$ & $(0.0306)$ \\
& & & \\
Log income 1999 & $0.0267^{* * *}$ & $0.0843^{* * *}$ & $0.1587^{* * *}$ \\
and log deviation income 1999 and 2000 & $(0.0079)$ & $(0.0132)$ & $(0.0164)$ \\
\hline Observations & 160,065 & 160,065 & 160,065 \\
\hline \hline
\end{tabular}

Notes: Heteroscedasticity robust standard errors in parentheses, ${ }^{* * *} \mathrm{p}<0.01, * * \mathrm{p}<0.05, * \mathrm{p}<0.1$. Observations are weighted by population weights and 2000 income. Base specification projecting synthetic incomes out of 2000 and using socioeconomic individual and household characteristics and sector dummies for 2000. Sample is restricted to individuals with labour income $>10,000$ euro in 2000 . 
year. ${ }^{27}$ When we use 2000 instead of 1999 as the base year, we find an elasticity of 0.18 compared to 0.24 in the baseline using log base-year income, and 0.21 compared to 0.22 using the 5-piece spline. One potential advantage of using 2000 as the base year is that we can include the log of 1999 income as well as the log difference between 1999 and 2000 income, following Kopczuk (2005). This allows for a separate treatment of mean reversion and differential trends. Using these income controls we find a somewhat lower elasticity of 0.16 than the 0.18 when using only log year 2000 income.

In Table 6 we consider the outcomes of the base specification for different income subgroups. We focus on the results for the period 1999-2005. We estimate somewhat lower elasticities for the low income group (10-50K): 0.22 using log base-year income and 0.12 using the 5 -piece spline. ${ }^{28}$ Our preferred specification is with log base-year income, since the 5-piece spline is more likely to soak up part of the remaining variation in the smaller income segment. For the group with income between 50$100 \mathrm{~K}$, we estimate an elasticity of 0.20 using log base-year income, and the estimate drops somewhat to 0.17 when we include a 5 -piece spline. For the group with income above $50 \mathrm{~K}$, without upper bound ${ }^{29}$, we estimate the largest elasticities. Using log base-year income as a control the estimate is 0.45 , but this drops substantially to 0.27 when we include the 5 -piece spline. Differential trends may play a role for the higher incomes, and it is not directly clear which specification is to be preferred for this group. However, our finding that taxable or broad income elasticities are higher for higher incomes is consistent with the literature (Saez et al., 2012).

We also estimate the base regressions separately for single men and women, and for men and women in couples. The results can be found in Table 7 . We find larger elasticities for single women than for single men, and also (much) larger elasticites for women in couples than for men in couples. ${ }^{30}$ The elasticity for single women is somewhat lower than for women in couples, whereas the elasticity for single men is higher than for men in couples.

Finally, also of interest is the size of the elasticity of taxable labour income

\footnotetext{
${ }^{27}$ We prefer 1999 as the base year, because there might be anticipation effects.

${ }^{28}$ For each income subgroup we construct a new spline in log base-year income.

${ }^{29} \mathrm{We}$ always need to include medium income individuals as a control group, since we need a control group where there was hardly any change in effective marginal tax rates.

${ }^{30}$ For Sweden, Blomquist and Selin (2010) also find that taxable income elasticities are larger for women than for men, whereas Ericson et al. (2015) find the reverse.
} 
Table 6: Heterogeneity: results for income subgroups

\begin{tabular}{lccc}
\hline \hline & $(1)$ & $(2)$ & $(3)$ \\
Period & $1999-2001$ & $1999-2003$ & $1999-2005$ \\
\hline Income 10-50K & & & \\
Log base-year income & $0.0829^{* * *}$ & $0.1430^{* * *}$ & $0.2164^{* * *}$ \\
& $(0.0076)$ & $(0.0092)$ & $(0.0116)$ \\
5-piece spline in base-year income & $0.0616^{* * *}$ & $0.0859^{* * *}$ & $0.1234^{* * *}$ \\
& $(0.0135)$ & $(0.0139)$ & $(0.0197)$ \\
Observations & 148,221 & 148,221 & 148,221 \\
& & & \\
Income 50-100K & & & \\
Log base-year income & $0.1605^{* * *}$ & $0.1401^{* * *}$ & $0.2012^{* * *}$ \\
& $(0.0262)$ & $(0.0347)$ & $(0.0418)$ \\
5-piece spline in base-year income & $0.0824^{* *}$ & $0.0692^{* *}$ & $0.1685^{* *}$ \\
& $(0.0416)$ & $(0.0548)$ & $(0.0698)$ \\
Observations & 11,516 & 11,516 & 11,516 \\
& & & \\
Income $>50 K$ & & & \\
Log base-year income & & & \\
5-piece spline in base-year income & $0.0804^{*}$ & $0.1312^{* *}$ & $0.2664^{* * *}$ \\
& $(0.0443)$ & $(0.0566)$ & $(0.0814)$ \\
\hline \hline
\end{tabular}

Notes: Heteroscedasticity robust standard errors in parentheses, ${ }^{* * *} \mathrm{p}<0.01,{ }^{* *} \mathrm{p}<0.05$, $* \mathrm{p}<0.1$. Observations are weighted by population weights and 1999 income. Base specification projecting synthetic incomes out of 1999 and using socioeconomic individual and household characteristics and sector dummies for 1999. 
Table 7: Heterogeneity: results by household type and gender

\begin{tabular}{|c|c|c|c|}
\hline Period & $\begin{array}{c}(1) \\
1999-2001\end{array}$ & $\begin{array}{c}(2) \\
1999-2003\end{array}$ & $\begin{array}{c}(3) \\
1999-2005\end{array}$ \\
\hline \multicolumn{4}{|l|}{ Single men } \\
\hline Log base-year income & $\begin{array}{c}0.0677 \\
(0.0728)\end{array}$ & $\begin{array}{l}0.1791^{* * *} \\
(0.0350)\end{array}$ & $\begin{array}{l}0.2836^{* * *} \\
(0.0950)\end{array}$ \\
\hline 5-piece spline in base-year income & $\begin{array}{c}-0.0016 \\
(0.0436)\end{array}$ & $\begin{array}{l}0.1513^{* * *} \\
(0.0548)\end{array}$ & $\begin{array}{l}0.2865^{* * *} \\
(0.1105)\end{array}$ \\
\hline Observations & 11,114 & 11,114 & 11,114 \\
\hline \multicolumn{4}{|l|}{ Single women } \\
\hline Log base-year income & $\begin{array}{l}0.1698^{* * *} \\
(0.0294)\end{array}$ & $\begin{array}{l}0.3205^{* * *} \\
(0.0424)\end{array}$ & $\begin{array}{l}0.4270^{* * *} \\
(0.0500)\end{array}$ \\
\hline 5-piece spline in base-year income & $\begin{array}{l}0.1186^{* * *} \\
(0.0370)\end{array}$ & $\begin{array}{l}0.2131^{* * *} \\
(0.0541)\end{array}$ & $\begin{array}{l}0.3199^{* * *} \\
(0.0672)\end{array}$ \\
\hline Observations & 10,194 & 10,194 & 10,194 \\
\hline \multicolumn{4}{|l|}{ Men in couples } \\
\hline Log base-year income & $\begin{array}{c}0.0290^{*} \\
(0.0149)\end{array}$ & $\begin{array}{l}0.0603^{* * *} \\
(0.0244)\end{array}$ & $\begin{array}{l}0.1047^{* * *} \\
(0.0214)\end{array}$ \\
\hline 5-piece spline in base-year income & $\begin{array}{c}0.0556^{* *} \\
(0.0448)\end{array}$ & $\begin{array}{l}0.1298^{* * *} \\
(0.0423)\end{array}$ & $\begin{array}{l}0.1453^{* * *} \\
(0.0407)\end{array}$ \\
\hline Observations & 97,190 & 97,190 & 97,190 \\
\hline \multicolumn{4}{|l|}{ Women in couples } \\
\hline Log base-year income & $\begin{array}{l}0.1956^{* * *} \\
(0.0268)\end{array}$ & $\begin{array}{l}0.4273^{* * *} \\
(0.0464)\end{array}$ & $\begin{array}{l}0.4566^{* * *} \\
(0.0400)\end{array}$ \\
\hline 5-piece spline in base-year income & $\begin{array}{l}0.2432^{\text {*** }} \\
(0.0557)\end{array}$ & $\begin{array}{l}0.4081^{* * *} \\
(0.0738)\end{array}$ & $\begin{array}{l}0.4764^{* * *} \\
(0.0858)\end{array}$ \\
\hline Observations & 42,103 & 42,103 & 42,103 \\
\hline
\end{tabular}

Notes: Heteroscedasticity robust standard errors in parentheses, ${ }^{* * *} \mathrm{p}<0.01,{ }^{* *} \mathrm{p}<0.05$, $* \mathrm{p}<0.1$. Observations are weighted by population weights and 1999 income. Base specification projecting synthetic incomes out of 1999 and using socioeconomic individual and household characteristics and sector dummies for 1999. Sample is restricted to individuals with labour income >10,000 euro in 1999. 
Table 8: Elasticity of taxable labour income vs. hours worked

\begin{tabular}{lccc}
\hline \hline & $(1)$ & $(2)$ & $(3)$ \\
Period & $1999-2001$ & $1999-2003$ & $1999-2005$ \\
\hline All workers & & & \\
Taxable labour income & $0.0863^{* * *}$ & $0.1496^{* * *}$ & $0.2071^{* * *}$ \\
& $(0.0085)$ & $(0.0118)$ & $(0.0140)$ \\
Hours worked & 0.0044 & $0.0340^{* * *}$ & $0.0466^{* * *}$ \\
& $(0.0085)$ & $(0.0106)$ & $(0.0110)$ \\
\hline Observations & 68,223 & 68,223 & 68,223 \\
\hline \hline
\end{tabular}

relative to the elasticity of hours worked, to see how much of the estimated response is due to a change in labour supply and how much is due to other factors. We do not have full coverage of hours worked, about 40 percent of the workers are covered in the data set, which are mostly workers in the public sector and in large companies. For these workers we estimate an ETI of $0.21^{31}$ and a contractual annual hours worked elasticity of $0.05 .{ }^{32,33}$ Hence, the labour supply response captures only

\footnotetext{
${ }^{31}$ This estimate is somewhat lower than the 0.24 for the full sample, which may be be due to the fact that there are less opportunities to change taxable income in the public sector or in large firms.

${ }^{32}$ This intensive labour supply elasticity is in line with estimates of the labour supply literature, see Bargain et al. (2014) for an overview for European countries and the US, and Jongen et al. (2014) for recent estimates for the Netherlands.

${ }^{33}$ Table A.5 in the appendix also gives the taxable labour income elasticities and hours worked elasticities for demographic subgroups. Also for the subsample for which we observe taxable labour income and contractual hours worked, taxable labour income elasticities are larger for women than for men, and the taxable labour income elasticities are typically much larger than the contractual
} 
part of the tax base response. This is consistent with the findings of Moffitt and Wilhelm (2000) for high incomes in the US, but quite different from the findings of Thoresen and Vatto (2015) for Norway. We should note though that we measure contractual hours worked. To the extent that individuals work more hours due to the tax reform but this does not show up in their contractual working hours (e.g. top income earners), we may underestimate the hours worked response. However, note that the elasticity of taxable labour income also captures other effects on the tax base, like e.g. changes in effort more generally, changes in occupational choice and changes in tax avoidance via work-related tax deductibles.

\section{Discussion and concluding remarks}

In this paper we have estimated the elasticity of taxable labour income in the Netherlands. In our base specification, using log base-year income to control for mean reversion, for all workers we find an elasticity of 0.10 in the short run (1999-2001) rising to 0.24 in the medium to longer run (1999-2005). This elasticity is robust to how we control for exogenous income growth, the lower income threshold and the choice of base year. Our estimate is in between the higher estimates for Anglo-Saxon countries and the lower estimates for Scandinavia. Furthermore, our estimate is close to the recent estimates for France and Germany. We also find that the elasticity is higher for persons with a high income and also higher for women. Furthermore, we find that the elasticity of taxable labour income is higher than the elasticity of (contractual) annual hours worked, indicating that the (contractual) hours worked responses do not capture all tax base responses.

Our findings have potential important implications for policymaking. In particular, when there are no fiscal or other externalities associated with the tax base responses, the deadweight loss from marginal tax rates are substantially higher when using the elasticity of taxable labour income than using the elasticity of (contractual) annual hours worked. For example, using a value of 0.25 for the elasticity of the tax base of the top rate, Jacobs et al. (2013) calculate that the current top tax rate is close to the top of the Laffer-curve.

We conclude by noting that there are a number of limitations to our data set hours worked elasticities. 
and our tax-benefit calculator that prevent us from studying a number of additional issues. First, we cannot control for income effects since we have no information on unearned income. However, most ETI studies find that income effects are relatively small compared to substitution effects (Saez et al., 2012). Second, although we have self-employed in our data set, we cannot study their ETI because we do not have a tax-benefit calculator to calculate their effective marginal tax rate. ${ }^{34}$ Third, we would like to have longer pre-reform data on income, so that we can better control for exogenous income growth and address remaining concerns about the potential endogeneity of the net-of-tax rate instrument (Weber, 2014). Finally, we would like to have more information on tax deductibles, so that we can decompose the changes in the ETI into its components and also estimate the elasticity of taxable income. In this respect the IPO (Income Panel) data set of Statistics Netherlands looks promising. This data set is available for a much longer pre-reform period, and has information on unearned income and additional information on tax deductibles. However, for the moment there is no tax-benefit calculator for the IPO for the years before 2001.

\section{References}

Aarbu, K. and Thoresen, T. (2001). Income responses to tax changes - Evidence from the Norwegian tax reform. National Tax Journal, 54(2):319-338.

Afman, E. (2006). De Nederlandse inkomensverdeling, overheidsuitgaven en macroeconomische omstandigheden. mimeo.

Auten, G. and Carroll, R. (1999). The effect of income taxes on household behavior. Review of Economics and Statistics, 81(4):681-693.

Bargain, O., Orsini, K., and Peichl, A. (2014). Comparing labor supply elasticities in Europe and the United States: New results. Journal of Human Resources, 49(3):723-838.

\footnotetext{
${ }^{34}$ In a recent paper, Bosch and De Boer (2019) estimate the elasticity of profit income for selfemployed, using a new version of the tax-benefit calculator that can be used to calculate effective marginal tax rates for the self-employed.
} 
Blomquist, S. and Selin, H. (2010). Hourly wage rate and taxable labor income responsiveness to changes in marginal tax rates. Journal of Public Economics, 94:878-889.

Bosch, N. and De Boer, H.-W. (2019). Income and occupational choice responses of the self-employed to tax rate changes: Heterogeneity across reforms and income. Labour Economics, 58:1-20.

Bosch, N., Jongen, E., Leenders, W., and Mohlmann, J. (2019). Non-bunching at kinks and notches in cash tranfers in the Netherlands. International Tax and Public Finance, forthcoming.

Burns, S. and Ziliak, J. (2017). Identifying the elasticity of taxable income. Economic Journal, 127(600):297-329.

Chetty, R. (2009). Is the taxable income elasticity sufficient to calculate deadweight loss? The implications of evasion and avoidance. American Economic Journal: Economic Policy, 1(2):31-52.

Chetty, R. (2012). Bounds on elasticities with optimization frictions: A synthesis of micro and macro evidence on labor supply. Econometrica, 80(3):969-1018.

Dekker, V., Strohmaier, K., and Bosch, N. (2016). A data-driven procedure to determine the bunching window: An application to the Netherlands. Discussion Paper 336, CPB Netherlands Bureau for Economic Policy Analysis.

Doerrenberg, P., Peichl, A., and Siegloch, S. (2017). The elasticity of taxable income in the presence of deduction possibilities. Journal of Public Economics, 151:41-55.

Ericson, P., Flood, L., and Islam, N. (2015). Taxes, wages and working hours. Empirical Economics, 49:503-535.

Feldstein, M. (1995). The effect of marginal tax rates on taxable income: A panel study of the 1986 Tax Reform Act. Journal of Political Economy, 103(3):551-572.

Feldstein, M. (1999). Tax avoidance and the deadweight loss of the income tax. Review of Economics and Statistics, 81:674-680. 
Gelber, A. (2014). Taxation and the earnings of husbands and wives: Evidence from Sweden. Review of Economics and Statistics, 96(2):287-305.

Gruber, J. and Saez, E. (2002). The elasticity of taxable income: Evidence and implications. Journal of Public Economics, 84:1-32.

Hansson, A. (2007). Taxpayers' responsiveness to tax rate changes and implications for the cost of taxation in Sweden. International Tax and Public Finance, 14:563582 .

Holmlund, B. and Soderstrom, M. (2011). Estimating dynamic income responses to tax reform. The B.E. Journal of Economic Analysis \& Policy, 11(1).

Jacobs, B., Jongen, E., and Zoutman, F. (2013). Meer over de top. CPB Background Document, The Hague.

Jongen, E., De Boer, H.-W., and Dekker, P. (2014). MICSIM - A behavioural microsimulation model for the analysis of tax-benefit reform in the Netherlands. CPB Background Document, The Hague.

Jongen, E. and Stoel, M. (2013). Estimating the elasticity of taxable labour income in the Netherlands. CPB Background Document, The Hague.

Kleven, H. (2016). Bunching. Annual Review of Economics, 8:435-464.

Kleven, H. and Schultz, E. (2014). Estimating taxable income responses using Danish tax reforms. American Economic Journal: Economic Policy, 6(4):271301.

Knoef, M. (2011). Essays on Labor Force Participation, Ageing, Income and Health. CentER Dissertation Series, Tilburg.

Kopczuk, W. (2005). Tax bases, tax rates and the elasticity of reported income. Journal of Public Economics, 89(11-12):2093-2119.

Kopczuk, W. (2012). The Polish business "flat" tax and its effect on reported incomes: A Pareto improving tax reform? mimeo, Columbia University, New York. 
Lehmann, E., Marical, F., and Rioux, L. (2013). Labor income responds differently to income-tax and payroll-tax reforms. Journal of Public Economics, 99:66-84.

Moffitt, R. and Wilhelm, M. (2000). Taxation and the labor supply decisions of the affluent. In Slemrod, J., editor, Does Atlas Shrug? The Economic Consequences of Taxing the Rich, pages 193-234. Russell Sage Foundation, New York.

Saez, E. (2010). Do taxpayers bunch at kink points? American Economic Journal: Economic Policy, 2(3):180-212.

Saez, E., Slemrod, J., and Giertz, S. (2012). The elasticity of taxable income with respect to marginal tax rates: A critical review. Journal of Economic Literature, 50:1:3-50.

Sillamaa, M.-A. and Veall, M. (2001). The effect of marginal tax rates on taxable income: A panel study of the 1988 tax flattening in Canada. Journal of Public Economics, 80:341-356.

Statistics Netherlands (2009). Documentatierapport Arbeidsmarktpanel 1999$2005 \mathrm{~V} 1$.

Thoresen, T. and Vatto, T. (2015). Validation of the discrete choice labor supply model by methods of the new tax responsiveness literature. Labour Economics, $37: 38-53$.

Weber, C. (2014). Towards obtaining a consistent estimate of the elasticity of taxable income using difference-in-differences. Journal of Public Economics, 117:90-103. 
Appendix 


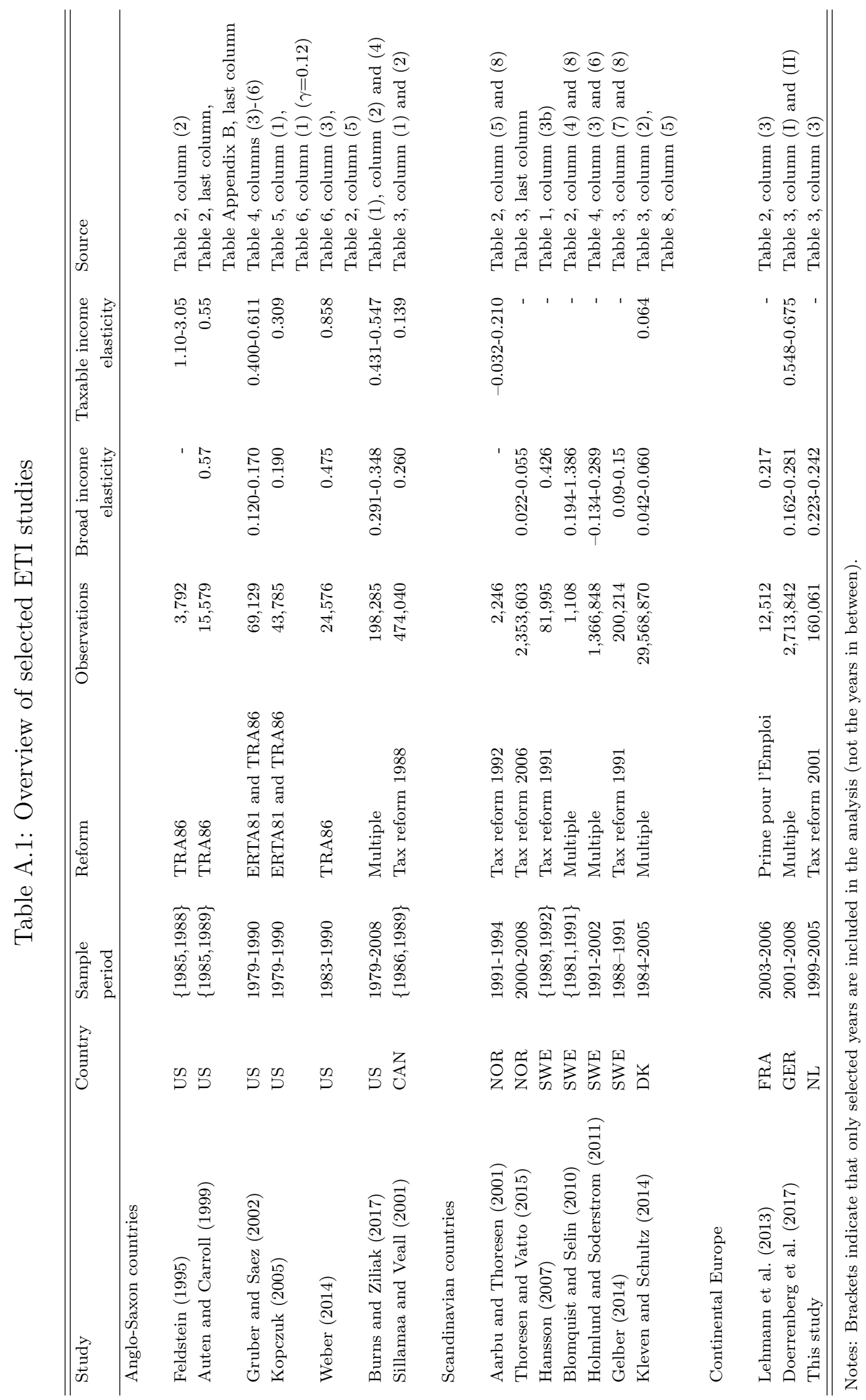


Table A.2: Full estimation results with log base-year income

\begin{tabular}{|c|c|c|c|}
\hline & (1) & $(2)$ & $(3)$ \\
\hline Period & 1999-2001 & 1999-2003 & 1999-2005 \\
\hline \multirow[t]{2}{*}{ Net-of-tax rate } & $0.0970^{* * *}$ & $0.1657^{* * *}$ & $0.2415^{* * *}$ \\
\hline & $(0.0090)$ & $(0.0108)$ & $(0.0143)$ \\
\hline \multirow[t]{2}{*}{ Log base-year income } & $-0.0665^{* * *}$ & $-0.1259^{* * *}$ & $-0.1392^{* * *}$ \\
\hline & $(0.0071)$ & $(0.0105)$ & $(0.0121)$ \\
\hline \multirow[t]{2}{*}{ Lower secondary education } & $0.0104^{* * *}$ & $0.0116^{* * *}$ & $0.0161^{* * *}$ \\
\hline & $(0.0027)$ & $(0.0029)$ & $(0.0038)$ \\
\hline \multirow[t]{2}{*}{ Higher secondary education } & $0.0283^{* * *}$ & $0.0406^{* * *}$ & $0.0510^{* * *}$ \\
\hline & $(0.0035)$ & $(0.0035)$ & $(0.0043)$ \\
\hline \multirow[t]{2}{*}{ Tertiary education } & $0.0768^{* * *}$ & $0.1197^{* * *}$ & $0.1529^{* * *}$ \\
\hline & $(0.0050)$ & $(0.0051)$ & $(0.0061)$ \\
\hline \multirow[t]{2}{*}{ Female } & $-0.0524^{* * *}$ & $-0.0904^{* * *}$ & $-0.1179^{* * *}$ \\
\hline & $(0.0040)$ & $(0.0050)$ & $(0.0052)$ \\
\hline \multirow[t]{2}{*}{ Western immigrant } & $0.0092^{* *}$ & $0.0102^{* *}$ & 0.0060 \\
\hline & $(0.0040)$ & $(0.0041)$ & $(0.0060)$ \\
\hline \multirow[t]{2}{*}{ Non-Western immigrant } & 0.0028 & $0.0084^{* * *}$ & $0.0103^{* *}$ \\
\hline & $(0.0027)$ & $(0.0031)$ & $(0.0042)$ \\
\hline \multirow[t]{2}{*}{ Unmarried couple w/o children } & $-0.0118^{* * *}$ & $-0.0230^{* * *}$ & $-0.0295^{* * *}$ \\
\hline & $(0.0040)$ & $(0.0034)$ & $(0.0050)$ \\
\hline \multirow[t]{2}{*}{ Married couple w/o children } & $-0.0188^{* * *}$ & $-0.0186^{* * *}$ & $-0.0199^{* * *}$ \\
\hline & $(0.0040)$ & $(0.0033)$ & $(0.0050)$ \\
\hline \multirow[t]{2}{*}{ Unmarried couple w/ children } & 0.0025 & 0.0069 & $0.0185^{* *}$ \\
\hline & $(0.0068)$ & $(0.0061)$ & $(0.0088)$ \\
\hline \multirow[t]{2}{*}{ Married couple w/ children } & -0.0029 & $0.0075^{* * *}$ & $0.0148^{* * *}$ \\
\hline & $(0.0041)$ & $(0.0026)$ & $(0.0046)$ \\
\hline \multirow[t]{2}{*}{ Single parent } & $0.0274^{* * *}$ & $0.0460^{* * *}$ & $0.0740^{* * *}$ \\
\hline & $(0.0050)$ & $(0.0054)$ & $(0.0079)$ \\
\hline \multirow[t]{2}{*}{ Age } & $-0.0039^{* * *}$ & $-0.0029^{* *}$ & $0.0069^{* * *}$ \\
\hline & $(0.0010)$ & $(0.0011)$ & $(0.0014)$ \\
\hline \multirow[t]{2}{*}{ Age squared } & $0.0000^{* *}$ & 0.0000 & $-0.0002^{* * *}$ \\
\hline & $(0.0000)$ & $(0.0000)$ & $(0.0000)$ \\
\hline Observations & 160,601 & 160,601 & 160,601 \\
\hline
\end{tabular}

Notes: Heteroscedasticity robust standard errors clustered at the individual level in parentheses, * denotes significant at the $10 \%$ level, ** at the $5 \%$ level and $* * *$ at the $1 \%$ level. Observations are weighted by population weights and 1999 income. Base specification projecting synthetic incomes out of 1999 and using socioeconomic individual and household characteristics and sector dummies for 1999. Sector dummies are included but not reported (available on request). The sample is restricted to individuals with labour income >10,000 euro in 1999. 
Table A.3: Results for all reform years

\begin{tabular}{lccccc}
\hline \hline & $(1)$ & $(2)$ & $(3)$ & $(4)$ & $(5)$ \\
Period & $1999-2001$ & $1999-2002$ & $1999-2003$ & $1999-2004$ & $1999-2005$ \\
\hline $\begin{array}{l}\text { No pre-reform income } \\
\text { control }\end{array}$ & $0.0236^{* *}$ & $0.0204^{* *}$ & $0.0298^{* * *}$ & $0.0752^{* * *}$ & $0.0716^{* * *}$ \\
& $(0.0102)$ & $(0.0104)$ & $(0.0113)$ & $(0.0123)$ & $(0.0130)$ \\
& & & & \\
Log base-year income & $0.1003^{* * *}$ & $0.1276^{* * *}$ & $0.1724^{* * *}$ & $0.2352^{* * *}$ & $0.2442^{* * *}$ \\
& $(0.0090)$ & $(0.0103)$ & $(0.0109)$ & $(0.0128)$ & $(0.0144)$ \\
& & & & \\
5-piece spline in log & $0.0816^{* * *}$ & $0.1583^{* * *}$ & $0.1856^{* * *}$ & $0.2371^{* * *}$ & $0.2333^{* * *}$ \\
base-year income & $(0.0395)$ & $(0.0413)$ & $(0.0348)$ & $(0.0356)$ & $(0.0363)$ \\
\hline Observations & 157,249 & 157,249 & 157,249 & 157,249 & 157,249 \\
\hline \hline
\end{tabular}

Notes: Heteroscedasticity robust standard errors in parentheses, ${ }^{* * *} \mathrm{p}<0.01,{ }^{*} \mathrm{p}<0.05, * \mathrm{p}<0.1$. Observations are weighted by population weights and 1999 income. Base specification projecting synthetic incomes out of 1999 and using socioeconomic individual and household characteristics and sector dummies for 1999. The sample is restricted to individuals with labour income $>10,000$ euro in 1999 .

Table A.4: Results using different sample selections for the maximum (absolute) change in the net-of-tax rate

\begin{tabular}{lcccl}
\hline \hline & $(1)$ & $(2)$ & $(3)$ & \\
Period & $1999-2001$ & $1999-2003$ & $1999-2005$ & Observations \\
\hline Change in net-of-tax rate $\mid<=100 \%$ & $0.0858^{* * *}$ & $0.1142^{* * *}$ & $0.1820^{* * *}$ & 175,763 \\
& $(0.0256)$ & $(0.0115)$ & $(0.0159)$ & \\
$\mid$ Change in net-of-tax rate $\mid<=75 \%$ & $0.0855^{* * *}$ & $0.1125^{* * *}$ & $0.1853^{* * *}$ & 173,855 \\
& $(0.0261)$ & $(0.0115)$ & $(0.0159)$ & \\
$\mid$ Change in net-of-tax rate $\mid<=50 \%$ & $0.0899^{* * *}$ & $0.1208^{* * *}$ & $0.1873^{* * *}$ & 171,244 \\
& $(0.0260)$ & $(0.0115)$ & $(0.0153)$ & \\
$\mid$ Change in net-of-tax rate $\mid<=40 \%$ & $0.1017^{* * *}$ & $0.1363^{* * *}$ & $0.2125^{* * *}$ & 168,944 \\
& $(0.0267)$ & $(0.0115)$ & $(0.0153)$ & \\
$\mid$ Change in net-of-tax rate $\mid<=30 \%^{a}$ & $0.0970^{* * *}$ & $0.1657^{* * *}$ & $0.2415^{* * *}$ & 160,601 \\
& $(0.0090)$ & $(0.0108)$ & $(0.0143)$ & \\
\hline \hline
\end{tabular}

Notes: Heteroscedasticity robust standard errors clustered at the individual level in parentheses, ${ }^{*}$ denotes significant at the $10 \%$ level, ** at the $5 \%$ level and ${ }^{* * *}$ at the $1 \%$ level. Observations are weighted by population weights and 1999 income. Base specification, using log base-year income as the income control, projecting synthetic incomes out of 1999 and using socioeconomic individual and household characteristics and sector dummies for 1999. Sector dummies are included but not reported (available on request). The sample is restricted to individuals with labour income $>10,000$ euro in 1999 . ${ }^{a}$ Base specification. 
Table A.5: Heterogeneity elasticity of taxabe labour income vs. hours worked: results by household type and gender

\begin{tabular}{|c|c|c|c|}
\hline & $(1)$ & $(2)$ & $(3)$ \\
\hline Period & 1999-2001 & 1999-2003 & 1999-2005 \\
\hline \multicolumn{4}{|l|}{ Single men } \\
\hline \multirow[t]{2}{*}{ Taxable labour income } & $0.0707^{* * *}$ & $0.0951^{* * *}$ & $0.0924^{*}$ \\
\hline & $(0.0273)$ & $(0.0337)$ & $(0.0519)$ \\
\hline \multirow[t]{2}{*}{ Hours worked } & $0.0811^{* *}$ & 0.0310 & $0.0745^{* *}$ \\
\hline & $(0.0315)$ & $(0.0254)$ & $(0.0300)$ \\
\hline Observations & 4,015 & 4,015 & 4,015 \\
\hline \multicolumn{4}{|l|}{ Single women } \\
\hline \multirow[t]{2}{*}{ Taxable labour income } & $0.1144^{* * *}$ & $0.2057^{* * *}$ & $0.3047^{* * *}$ \\
\hline & $(0.0368)$ & $(0.0637)$ & $(0.0694)$ \\
\hline \multirow[t]{2}{*}{ Hours worked } & 0.0598 & $0.1936^{* * *}$ & $0.1394^{* *}$ \\
\hline & $(0.0394)$ & $(0.0458)$ & $(0.0550)$ \\
\hline Observations & 5,059 & 5,059 & 5,059 \\
\hline \multicolumn{4}{|l|}{ Men in couples } \\
\hline \multirow[t]{2}{*}{ Taxable labour income } & $0.0201^{* *}$ & 0.0191 & 0.0095 \\
\hline & $(0.0097)$ & $(0.0130)$ & $(0.0176)$ \\
\hline \multirow[t]{2}{*}{ Hours worked } & $0.0154^{* * *}$ & $0.0366^{* * *}$ & $0.0530^{* * *}$ \\
\hline & $(0.0058)$ & $(0.0085)$ & $(0.0087)$ \\
\hline Observations & 37,668 & 37,668 & 37,668 \\
\hline \multicolumn{4}{|l|}{ Women in couples } \\
\hline \multirow[t]{2}{*}{ Taxable labour income } & $0.1833^{* * *}$ & $0.3324^{* * *}$ & $0.4224^{* * *}$ \\
\hline & $(0.0226)$ & $(0.0308)$ & $(0.0305)$ \\
\hline \multirow[t]{2}{*}{ Hours worked } & -0.0363 & 0.0470 & $0.0813^{* * *}$ \\
\hline & $(0.0264)$ & $(0.0324)$ & $(0.0295)$ \\
\hline Observations & 21,481 & 21,481 & 21,481 \\
\hline
\end{tabular}

Notes: Heteroscedasticity robust standard errors in parentheses, ${ }^{* * *} \mathrm{p}<0.01$, ** $\mathrm{p}<0.05,{ }^{*} \mathrm{p}<0.1$. Observations for taxable labour income are weighted by population weights and 1999 income. Observations for hours worked are weighted by population weights and 1999 hours worked. Base specification projecting synthetic incomes out of 1999 and using socioeconomic individual and household characteristics and sector dummies for 1999. Using log baseyear income and log base-year hours worked to control for mean reversion in income and hours worked, respectively. Sample is restricted to individuals with labour income >10,000 euro in 1999 and for which hours worked are observed. 